\title{
Model Tax Avoidance of Indonesian Property Companies within the Perspectives of Size, Sales and Corporate Governance
}

\section{Niswah Baroroh and Rita Apriyanti}

Accounting Department, Economics Faculty, Universitas Negeri Semarang - Indonesia

\section{Abstract}

This research aims to determine the influences of the company's size, sales growth, and independent commissioner on the tax avoidance with audit quality as a moderating variable. The population of this research is the property and real estate companies registered on the Indonesia Stock Exchange within the period 2014-2017. The sample is selected using purposive sampling method covering 26 companies. The data analysis tools used are descriptive analysis and multiple linear regression with SPSS version 23. The results of the research show that company's size and sales growth have a significant and positive effect on the tax avoidance, while the independent

Corresponding Author: Niswah Baroroh

niswahbaroroh@mail.unnes.ac.id

Received: 7 February 2020

Accepted: 9 March 2020

Published: 23 March 2020

Publishing services provided by

Knowledge E

(c) Niswah Baroroh and Rita

Apriyanti. This article is

distributed under the terms of

the Creative Commons.

Attribution License, which

permits unrestricted use and

redistribution provided that the

original author and source are

credited.

Selection and Peer-review under

the responsibility of the

ICE-BEES 2019 Conference

Committee. commissioner does not show any significant influence. The audit quality moderates the influence of sales growth on the tax avoidance, but it does not moderate the influence of the company size and independent commissioner on the tax avoidance. The future researchers are suggested to use other different proxies to measure the independent commissioner to describe the condition of the company's independent commissioner.

Keywords: Tax Avoidance; Company Size; Sales Growth; Independent Commissioner; Audit Quality

\section{Introduction}

The tax that is included as the income for the company become a burden that must be paid by the taxpayers without getting any compensation directly. This difference of interests makes the taxpayers make certain efforts to avoid it so that the taxes paid are low. Therefore, the profits obtained can as maximum as possible.

One of the efforts made by the company to minimize the tax expense is the tax avoidance. Tax avoidance aims to reduce the tax expense paid but done legally in accordance with aplicable laws and regulations on the taxation.

The tax avoidance sometimes plunges the company into detrimental legality cases, such as the taxation cases that occur at IKEA, the European Union and SPL which show that the tax avoidance conducted by those companies is not appropriate, causing losses 
towards themselves. The losses that arise include increasing the tax expense that must be paid and having to deal with the law enforcement officers due to inappropriate tax avoidance procedures.

Based on positive accounting theory, the accounting method used by the company does not have to be the same as the others, but it is given the freedom to choose one of the available alternative methods to minimize contract costs and maximize the company value (Merslythalia \& Lasmana, 2016). This freedom makes the managers tend to carry out opportunistic actions. The actions are related to the managers'decisions who choose certain policies that can benefit their own companies.

Several previous studies have showed different results. Putri \& Suryarini (2017), Putri \& Putra (2017), Dharma \& Ardiana (2016) and Mahanani \& Titisari (2016) stated that the company size has a positive effect on tax avoidance. The larger the size of the company, the more complex transactions within the company that may cause various gaps to reduce the tax expense. Different result is shown by Praditasari \& Setiawan (2017) stating that the greater the size of the company, the greater the supervision given to the company by the government which results in many big companies which tend to have greater effective tax rates, which means that they avoid the tax avoidance. On the other hand, Merslythalia \& Lasmana (2014) found that company size does not affect tax avoidance.

Dharma \& Ardiana (2016) and Turyatini (2017) explained that the size is the level of the size of a company. The large size of the company will have an impact on the tax expense paid to the government. The bigger a company, the greater the tax expense that must be paid. Referring to the positive accounting theory, if the company is faced with political costs, it will have a larger size that is is required by the state to pay higher amounts of tax. However, rarely do many companies that want voluntarily and sincerely to pay the tax with higher nominal, because it can reduce their corporate profits. The large size companies tend to do the tax avoidance. The tax paid by the company is a deduction result from its profits, so it must be minimized as well as possible.

\section{$\mathbf{H}_{1}$ : The company size positively influences the tax avoidance}

The sales growth is also a factor that influences the tax avoidance. Sales growth is a change in sales per year from an entity (Furi, 2018). Mahanani \& Titisari (2016), and Dewinta \& Setiawan (2016) stated that the sales growth has a positive effect on the tax avoidance. The higher the sales growth, the higher also the tax avoidance of a company. Different result is presented by Oktaviyani \& Munandar (2017) who stated that the sales growth does not affect the tax avoidance 
Sales growth is part of the indicator of demand and competition for a company. A condition where the sales growth has increased means that the profits obtained by the company also increase. This illustrates that with higher sales growth, the company tends to do tax avoidance. This is based on agency theory which states that the managers as humans will act selfishly and tend to avoid risks in terms of paying corporate tax expense.

The sales growth indicates the development of sales from year to year. Increased sales allow the company to its operating capacity. Increasing the operating capacity will increase the profits which causes increasing tax. This pushes the managers to carry out the tax avoidance. The sales growth has a positive effect on the tax avoidance, which means that the higher sales growth, the higher also the tax avoidance that the managers perform.

\section{$\mathbf{H}_{2}$ : The sales growth positively influences the tax avoidance}

Independent commissioner has no relationship with the board of directors within a company and other board members (Praditasari \& Setiawan, 2017). A research done by Sihaloho \& Pratomo (2013) showed that the independent commissioner has a significant positive effect on the tax avoidance. Different result is shown by Ariawan \& Setiawan (2017), Mulyani, Wijayanti, \& Masito (2018) who stated that independent commissioner have a negative effect on the tax avoidance which means that more number of independent commissioner and the companies that have high profitability are able to pay their tax expense and maintaining the corporate values before the shareholders will cause them to minimize their tax avoidance behavior. Different result is shown from the research conducted by Merslythalia \& Lasmana (2014) and Fadhila, Pratomo, \& Yudowati (2017), stating that independent commissioner do not influence the tax avoidance.

The independent commissioner must be neutral, and he does not serve as the director of related company, and has no relationship with related parties within the company. Based on the agency theory, according to Jensen \& Meckling (1976), the agency conflict can be overcome at the expense of agency costs. This agency fee is spent to monitor and control the actions of the managers, so that they do not behave in a way that harms the company. Independent commissioner has the task of overseeing the corporate management and being accountable to the shareholders (Fadhila et al., 2017). This supervision is carried out through the establishment of an independent board of commissioners

The independent commissioner will develop certain strategies that can benefit the company without violating applicable regulations, including tax-related strategies. The high level of supervision carried out by the independent commissioner will make the 
managers report the company's tax performance as-is. This is done to protect the welfare of the company's stakeholders. The managers will not over-avoid tax if the level of supervision from the independent commissioner is high. Thus, the independent commissioner have a negative influence on the tax avoidance, which means that the higher the percentage of independent commissioner, the lower the level of the tax avoidance, and vice versa.

\section{$\mathrm{H}_{3}$ : The independent commissioner negatively influences the tax avoidance}

The audit quality is thought to play a role in the influence of company size on the tax avoidance. The audit quality describes opinions in audited financial statements. The large size companies tend to do tax avoidance. The tax paid is a deduction from the profits, so it must be minimized as best as possible. The high company profits will attract many investors to invest in it. The larger size of a company also means more competent human resources, so that the tax avoidance will be more effectively applied. Audit quality can reduce the practice of tax avoidance, because the audited financial statements will reflect the actual conditions for the company. Although the existence of audit quality can reduce the tax avoidance practice, but through good audit quality, the investors will trust and be interested to invest in the company. The companies audited by the Big Four KAP can be said to have better audit quality than those audited by nonBig Four KAP (Mulyani et al., 2018).

H4: The audit quality moderates the influence of company size on the tax avoidance

The companies audited by the Big Four KAP can be said to have better quality audit than those audited by non-Big Four KAP (Mulyani et al. 2018). Thise that have good audit quality reflect high quality audited financial statements. This makes the company feel that it has good financial performance and is able to manage its income and payment of corporate taxes, so that it tends not to perform the tax avoidance. The sales growth describes the development of sales from year to year. Increased sales allow the company to increase its operating capacity. Increasing operating capacity will also increase the profits which also causes the $c$ tax expense to increase. This causes the managers to carry out thetax avoidance. The audit quality will prevent tax avoidance behavior because good audit quality shows the more competent financial statements.

H5: The audit quality moderates the influence of sales growth on the tax avoidance

The audit quality will be a consideration of the shareholders in relation to investment decision making. The companies audited by The Big Four KAP have better quality than those audited by non-Big Four KAP (Mulyani et al. 2018). This will encourage the independent commissioner to perform more independent supervision, so that they can 
develop certain strategies that can benefit the company without violating applicable regulations, including tax-related strategies. The high level of supervision carried out by the independent commissioner will make the managers report their tax performance as-is. This is done to protect the welfare of the company's stakeholders. The managers will not over-avoid taxes if the level of supervision of the independent commissioner is high.

H6: The audit quality moderates the influence of independent commissioner on the tax avoidance.

\section{Research Methods}

This study uses secondary data in the form of audited financial statements and annual report of the property and real estate and has been registered on the Stock Exchange for the period 2014-2017. The sampling technique uses non random (purposive sampling), which means the sample is selected based on certain criteria that are fit with the research objectives. The criteria used in the research can be seen in table 1.

TABLE 1: Criteria of Sample Selection

\begin{tabular}{l|l|l} 
No. & Criteria & Number \\
\hline $\begin{array}{l}\text { 1. } \\
\text { Property and Real Estate Companies registered on Indonesian Stock Exchange }\end{array}$ & 46 \\
\hline Property and Real Estate Companies which do not issue complete financial & (3) \\
\hline 3. & The companies which suffer from loss during the research period & (9) \\
\hline 4. & The companies which obtain tax benefits during the research period & (5) \\
\hline 5. & The companies which experience delisting during the research period & (3) \\
\hline The companies as the research samples & 26 \\
\hline Final number of analysis units of the research from $2014-2017$ (26 companies $\times 4$ years) & 104 \\
\hline Source: processed data, 2019 &
\end{tabular}

This research uses some variables including the company size, sales growth, and independent commissioner as the independent ones, and the dependent variable in this research is tax avoidance, while the moderating variable is audit quality. The operational definitions of each variable can be seen in Table 2 .

The data collection technique used in this study is documentation. The documentation technique in this study is conducted by collecting financial statements data and annual reports of audited property and real estate companies registered on the Indonesia Stock Exchange from 2014-2017 which will be used to measure each variable. 
TABLE 2: Operational Definitions.

\begin{tabular}{|c|c|c|c|}
\hline No. & Variable & Definition & Measurementt/ Indikator \\
\hline 1. & Tax Avoidance & $\begin{array}{l}\text { A legal way to avoid the tax payment } \\
\text { and does not violate the regulations } \\
\text { on the tax (Ribeiro et al., 2015). }\end{array}$ & $E T R=\frac{\text { Tax expense }}{\text { Prof it before the tax }}$ \\
\hline 2. & Company size & $\begin{array}{l}\text { A scale that determines menentukan } \\
\text { the size of a company that can be } \\
\text { seen from its total assets (Turyatini, } \\
\text { 2017) }\end{array}$ & Company size $=$ Ln Total Assets \\
\hline 3. & Sales Growth & $\begin{array}{l}\text { Sales changing/dynamics each year } \\
\text { (Oktaviyani \& Munandar, 2017). }\end{array}$ & Sales Growth $=\frac{\text { Sales }_{t}-\text { Sales }_{t-1}}{\text { Sales }_{t-1}}$ \\
\hline \multirow[t]{2}{*}{4.} & \multirow[t]{2}{*}{$\begin{array}{l}\text { Independent } \\
\text { Commissioner }\end{array}$} & \multirow{2}{*}{$\begin{array}{l}\text { The one who is not affiliated with } \\
\text { the shareholders as the controllers, } \\
\text { does not have affiliative connection } \\
\text { with the direction as well as acts as } \\
\text { the director within the company } \\
\text { (Ariawan \& Setiawan, 2017). }\end{array}$} & $\begin{array}{l}\text { Independen Commissioner }= \\
\text { Number of Board of Comissioner }\end{array}$ \\
\hline & & & Total Board of Commissioner \\
\hline 5. & Audit quality & $\begin{array}{l}\text { Audit quality can be measured } \\
\text { based on the size of the Public } \\
\text { Accounting Firm (KAP) that conducts } \\
\text { audits on a company (Dewi \& Jati, } \\
\text { 2014). }\end{array}$ & $\begin{array}{l}\text { Figure 0: The companies audited by } \\
\text { KAP The Big Four Figure } 0 \text { The } \\
\text { companies audited by KAP non The } \\
\text { Big Four. }\end{array}$ \\
\hline
\end{tabular}

Source: Previous Studies, 2019

\section{Research and Discussions}

The results of the descriptive statistics of the company size, sales growth, independent commissioner, tax avoidance, and quality audit are presented in table 3.

TABLE 3: Descriptive Statistics Results.

\begin{tabular}{|l|c|c|c|c|c|}
\hline & N & Minimum & Maximum & Mean & $\begin{array}{c}\text { Std. } \\
\text { Deviation }\end{array}$ \\
\hline SIZE & 94 & 25.890 & 31.670 & 29.48223 & 1.335294 \\
\hline GROW & 94 & -.912 & 4.369 & .15461 & .533023 \\
\hline IC & 94 & .200 & .833 & .40074 & .116825 \\
\hline AQ & 94 & 0 & 1 & .28 & .450 \\
\hline ETR & 94 & -.524 & -.012 & -.18654 & .101754 \\
\hline Valid N (listwise) & 94 & & & & \\
\hline
\end{tabular}

Source: Processed data, 2019

The mean of the variables of the company size and independent commissioner is higher than the standard deviation, which means that the data distribution on these variables is homogeneous. Therefore, it can be said that there is no difference between one to another company. However, in the variables of sales growth, audit quality, and 
tax avoidance, the mean is lower than the standard deviation, which means that the data are distributed heterogeneously.

Classical assumption test is used to achieve unbiased estimators. The results of the normality test show the Kolmogorov-Smirnov (K-S) value is 0.200 which is higher than the 0.05 significance level, so that the data are normally distributed. Multicollinearity test shows that the data are free from multicollinearity because all variables show VIF values $<10$ and tolerance values $>0.10$. The result of heterocedacity test indicates that the data are free from heterocedasticity because the value of $c^{2}$ count is lower than $c^{2}$ table. Meanwhile, the autocorrelation test shows the value of 0.147 . This is higher than 0.05 , so it can be concluded that there is no autocorrelation among the research data.

The coefficient value of determination of the adjusted $\mathrm{R}$ square is 0.162 . This means that $16.2 \%$ of tax avoidance variable that are proxied by effective tax rate (ETR) can be explained further by the independent variables in this study, namely the company size, sales growth, and independent commissioner. The moderating variable of this research is audit quality. The regression test equation can be written as follows:

The results of hypothesis testing can be seen in table 4 .

TABLE 4: Summary of Hypothesis Testing.

\begin{tabular}{|c|c|c|c|}
\hline Hypothesis & Statement & Sig. & Result \\
\hline $\mathrm{H}_{1}$ & $\begin{array}{l}\text { Company size positively and significantly influences } \\
\text { the tax avoidance }\end{array}$ & 0,043 & Accepted \\
\hline $\mathrm{H}_{2}$ & $\begin{array}{l}\text { Sales growth positively and significantly influences the } \\
\text { tax avoidance }\end{array}$ & 0,001 & Accepted \\
\hline $\mathrm{H}_{3}$ & $\begin{array}{l}\text { Independent commissioner negatively and significantly } \\
\text { influences the tax avoidance }\end{array}$ & .106 & Rejected \\
\hline $\mathrm{H}_{4}$ & $\begin{array}{l}\text { Audit quality moderates significantly influences the } \\
\text { company size on the tax avoidance }\end{array}$ & .592 & Rejected \\
\hline $\mathrm{H}_{5}$ & $\begin{array}{l}\text { Audit quality moderates significantly influences the } \\
\text { sales growth on the tax avoidance }\end{array}$ & .032 & Accepted \\
\hline $\mathrm{H}_{6}$ & $\begin{array}{l}\text { Audit quality moderates significantly influences the } \\
\text { independent commissioner on the tax avoidance }\end{array}$ & .175 & Rejected \\
\hline
\end{tabular}

Source: processed data, 2019

\subsection{The Influence of Company Size on the Tax Avoidance}

The results of the research show that the size of the company has a positive effect on the tax avoidance. Therefore, it can be concluded that $\mathbf{H} \mathbf{1}$ is accepted. This is in line with positive accounting theory which states that management is given a freedom to choose alternative methods to maximize the company value. The large size companies will also 
obtain higher profits, so the tax expense paid will also be greater. On the other hand, the tax expense will reduce the profits, so the management will look for alternatives to reduce the tax expense by conducting the tax avoidance

The results of this research are supported by the research of Putri and Suryarini (2017), Turyatini (2017) and Mahanani and Titisari (2016) which stated that the company size has a positive influence on the tax avoidance. Putri and Suryarini (2017 stated that the larger the size of the company, the more complex transactions within it, so that it may create loopholes to reduce the company's tax expense. This condition will cause management to conduct the tax avoidance to reduce the tax expense that the company will pay.

\subsection{The influence of Sales Growth on the Tax Avoidance}

Sales growth is an increase in the sales from the previous year. The results show that the sales growth has a positive effect on the tax avoidance, which means $\mathbf{H} \mathbf{2}$ is accepted. The results of this research prove that the relationship between the sales growth and tax avoidance supports the agency theory. Higher sales growth will increase the profits obtained by the company. Increasing company profits will also increase the tax expense paid by the company. The managers as the agents will try to conduct the tax avoidance in order to increase the value of the company and not reduce the agent's performance compensation for the sales growth. This indicates that the property and real estate companies in Indonesia carry out tax avoidance by utilizing the sales aspects.

The results of this research are in line with the research of Mahanani and Titisari (2016) and Dewinta and Setiawan (2016) which stated that the sales growth has a positive influence on the tax avoidance. Dewinta and Setiawan (2016) explained that increased sales growth enables the company to increase its operating capacity because with the increased sales growth, the company will also gain increased profits. This condition will cause an increase in the tax expense, the so that the management will try to minimize it by conducting the tax avoidance.

\subsection{The Influence of Independent Commissioner on the Tax Avoid- ance}

Independent commissioner is the most important part of the concept of Good Corporate Governance. The results of the statistical test show that the significance value of independent commissioner on the tax avoidance is higher than the value of significance 
level. Therefore, it can be concluded that $\mathbf{H} \mathbf{3}$ is rejected. There is no significant influence of independent commissions on the tax avoidance

The results of this research are not in line with the agency theory which states that the agency conflict can be overcome by expensing the agency costs. The agency cost is used to monitor and control the actions of the managers that may harm the company. It can be concluded that the role of independent commissioner within corporate governance functions has not been able to overcome conflicts of interest among the board of commissioners or shareholders, so that the managers tend to take risks by conducting tax avoidance, so that the concept of good corporate governance has not been achieved.

This is because the percentage of independent commissioner in the property and real estate companies is still relatively low; $62.77 \%$ of the total sample is still in the low category. Most companies only have 1 (one) independent commissioner out of a total of three. This means that most companies are only limited to meeting the minimum requirements of independent commissioner as determined by Bapepam $L K$, which states that a minimum proportion of independent commissioner in a company is $30 \%$. This causes the independent commissioner is wtill unable to effectively carry out the oversight role in making policies in the company, so that the independent commissioner does not influence the tax avoidance process.

This research is supported by research of Merslythalia and Lasmana (2016), Fadhila, et al. (2017), and Turyatini (2017) which stated that the independent commissioner has no influence on the tax avoidance due to the oversight function of independent commissioner that is not running well and maximally. This is because the placement of independent commissioner in the company is possible only to the extent of the formalities, thus inhibiting the supervision process by the independent commissioner on the company (Kiswanto et al. 2015).

\subsection{The Audit Quality Moderates the Influence of Company Size on the Tax Avoidance}

The results of hypothesis testing show the results of statistical testing of the moderating effect of audit quality on the relationship between the company size and tax avoidance. Based on the results of the test, it can be seen that the significance is $0.592>0.05$ with the negative coefficient of -0.010 . This indicates that the interaction between the company size and audit quality does not affect the tax avoidance, so $\mathbf{H 4}$ is rejected. 
These results deny the positive accounting theory that underlies the fourth hypothesis of this study. This is because the big companies will continue to carry out tax avoidance so that the tax expense remains low. In addition, most property and real estate companies as the research samples still rarely use the Big Four KAP in auditing their financial statements.

\subsection{The Audit Quality Moderates the Influence of Sales Growth on the Tax Avoidance}

The test results show the coefficient value of -0.031 with het significance level of 0.032 which means less than 0.05. Based on these results, it is known that the results of the interaction between the audit quality and sales growth have a significant effect on the tax avoidance actions. These results mean that audit quality weakens the effect of sales growth on the tax avoidance, so it can be concluded that $\mathbf{H} \mathbf{5}$ is accepted.

Based on the results above, it can be concluded that after the moderation of audit quality, the influence of sales growth on the tax avoidance shows a negative direction. This means that the audit quality can reduce the influence of sales growth on the tax avoidance. If the company has high sales growth, it tends to perform high tax avoidance too. On the other hand, good audit quality provides support for the managers not to take tax avoidance. Audit quality in this case acts as a control for the manager's behavior so that it can reduce the existence of tax avoidance and pay the tax expense in accordance with the actual situation.

\subsection{The Audit Quality Moderates the Influence of Independent Commissioner on the Tax Avoidance}

The results of this study indicate the coefficient value of -0.020 with the significance level of 0.175 which means more than 0.05 . Based on these results, it can be seen that the results of the interaction between the audit quality and independent commissioner does not influence the tax avoidance, so $\mathbf{H 6}$ is rejected.

These results deny the agency theory that underlies the sixth hypothesis of this study. This is because the level of independent commissioner owned by the sample companies is still low and the company's independent commissioner has not yet functioned optimally. On the other hand, this study uses audit quality as the moderating variable, but in reality, the results of the study indicate that the audit quality cannot strengthen or weaken the relationship between the independent commissioner and tax avoidance. 


\section{Conclusions}

The tax avoidance is influenced by the company size and sales growth. Independent commissioner does not affect the tax avoidance because the proportion of independent commissioner in property and real estate companies is still low. Audit quality moderates the influence of sales growth on the tax avoidance, but it cannot moderate the influence of the size of company and independent commissioner on the tax avoidance. Further research is required to use other variables to replace the moderating variable because it is proven that it cannot moderate the influence of company size and independent commissioner on the tax avoidance, and it can also be used to replace proxies from the independent commissioner, with others that better describe the true condition of the independent commissioner.

\section{References}

[1] Ariawan, I. M. A. R., \& Setiawan, P. E. (2017). Pengaruh Dewan Komisaris Independen, Kepemilikan Institusional, Profitabilitas dan Leverage Terhadap Tax Avoidance. EJurnal Akuntansi Universitas Udayana, 18(3), 1831-1859.

[2] Dewinta, I. A. R., \& Setiawan, P. E. (2016). Pengaruh Ukuran Perusahaan, Umur Perusahaan, Profitabilitas, Leverage, Dan Pertumbuhan Penjualan Terhadap Tax Avoidance. E-Jurnal Akuntansi Universitas Udayana ISSN: 2302-8556, 14(3), 15841613.

[3] Dharma, I. M. S., \& Ardiana, P. A. (2016). Pengarub Leverage, Intensitas ASet Tetap, Ukuran Perusahaan dan Koneksi Politik Terhadap Tax Avoidance. E-Jurnal Akuntansi Universitas Udayana, 15(1), 584-613.

[4] Fadhila, N. S., Pratomo, D., \& Yudowati, S. P. (2017). Pengaruh Kepemilikan Manajerial, Komisaris Independen dan Komite Audit Terhadap Tax Avoidance. EJurnal Akuntansi Universitas Udayana, 21(1), 1803-1820.

[5] Furi, G. D. (2018). Pengaruh Leverage, Ukuran Perusahaan, Inventory Intensity, Capital Intensity Ratio, Sales Growth, dan Komisaris Independen Terhadap Tax Avoidance, 1.

[6] Jensen, M. C., \& Meckling, W. H. (1976). Theory of the Firm: Managerial Behavior, Agency Costs and Ownership Structure Theory of the Firm: Managerial Behavior, Agency Costs and Ownership Structure. Journal of Financial Economics, 3(4), 305360. 
[7] Kiwanto, Sandy Arief, dan Linda Agustina. (2015). The Effect of Good Corporate Governance (GCG) Mechanism on Tax payable: Enterprise Risk Management as an Intervening Variable. International Conference on Accounting ICOA 2015. Vietnam.

[8] Mahanani, A., \& Titisari, K. H. (2016). Pengaruh Ukuran Perusahaan da Sales Growth Terhadap Tax Avoidance. Seminar Nasional Dan Call Paper Fakultas Ekonomi UNIBA Surakarta, 212-223.

[9] Merslythalia, D. R., \& Lasmana, M. S. (2016). Pengaruh Kompetensi Eksekutif, Ukuran Perusahaan, Komisaris Independen, dan Kepemilikan Institusional Terhadap Tax Avoidance, 11(2), 117-124.

[10] Mulyani, S., Wijayanti, A., \& Masitoh, E. (2018). Pengaruh Corporate Governance Terhadap Tax Avoidance.Jurnal Riset Akuntansi Dan Bisnis Airlangga, 3(1), 322340.

[11] Oktaviyani, R., \& Munandar, A. (2017). Effect of Solvency, Sales Growth, and Institutional Ownership on Tax Avoidance with Profitability as Moderating Variables in Indonesian Property and Real Estate Companies. Binus Business Review, 8(3), 183. https://doi.org/10.21512/bbr.v8i3.3622

[12] Praditasari, N. K. A., \& Setiawan, P. E. (2017). Pengaruh Good Corporate Governance, UKuran Perusahaan, Leverage, dan Profitabilitas Pada Tax Avoidance, 19(2), 12291258.

[13] Putri, T. R. F., \& Suryarini, T. (2017). Factors Affecting Tax Avoidance on Manufacturing Companies Listed on IDX. Accounting Analysis Journal, 6(3), 407-419.

[14] Putri, V. R., \& Putra, B. I. (2017). Pengaruh Leverage, Profitability, Ukuran Perusahaan dan Proporsi Kepemilikan Institusional Terhadap Tax Avoidance. Jurnal Ekonomi Manajemen Sumber Daya, 19(1), 1-11.

[15] Ribeiro, A., Cerqueira, A., \& Brandao, E. (2015). The Determinants of Effective Tax Rates: Firms' Characteristics and Corporate Governance. FEP Working Papers, 567, 1-45. https://doi.org/0870-8541

[16] Sihaloho, S., \& Pratomo, D. (2013). Pengaruh Corporate Governance dan Karakteristik Eksekutif Terhadap Tax Avoidance. Jurnal Akuntansi Universitas Telkom, 2(3), 34173425.

[17] Turyatini. (2017). The Analysis of Tax Avoidance Determinant on The Property and Real Estate Companies. Jurnal Dinamika Akuntansi, 9(2), 143-153. https://doi.org/ http://dx.doi.org/10.15294/jda.v9i2.10385 Received 